\title{
ATTITUDES OF CZECH AND SLOVAK YOUNG PROFESSIONALS TOWARDS POTENTIAL NEW ENTRANTS IN THE AUTOMOTIVE INDUSTRY
}

\author{
Denis Durec ${ }^{1}$, Marek Vins ${ }^{2 *}$
}

\begin{abstract}
Automotive industry is changing rapidly. Are these changes what the car customer prefers? This paper gives insights into attitudes towards new automotive brands, brand image of big tech companies, perceptions regarding the cooperation between car manufacturers and tech companies, purchasing drivers of new brands, and willingness to pay for big tech brands in automotive. Qualitative methodology was followed and thirty in-depth interviews with young professionals in Czech Republic and Slovakia were conducted with the use of an interview guide. Results showed that participants in general have positive attitudes towards tech companies that want to enter the automotive sector, however they express their concerns regarding their lack of experience.
\end{abstract}

Keywords automotive industry, OEMs, tech companies, new entrants

\section{INTRODUCTION}

The automotive industry is one of the most important industries in both Czech Republic and Slovakia. More specifically, it makes up more than 9\% of the Czech GDP and 13\% of the Slovak GDP and the automotive industry is $49,5 \%$ of industrial production in Slovakia and $26 \%$ in the Czech Republic. Only the pandemic caused by COVID-19 halted the annual rise of such numbers (Konicarová, 2019; Pravda, 2019; SME, 2020).

It is evident that the automotive industry goes through a period of transformation due to new technologies and rapid innovation. Research has shown that technological innovation has a significant positive impact on the performance of companies (Atalay, Anafarta, and Sarvan, 2013) and the findings of Talay, Calantone, and Voorhees (2013) have demonstrated that innovation is crucial for the survival of brands in the automotive industry. Nowadays, the automotive industry has reached a point where it is steadily shifting away from being focused only on the hardware elements as the software becomes central component of a vehicle (Diekhof, 2015). In addition, new players in the automotive market introduce disruptive technologies, business models, tactics, and strategies, aiming to alter the vertically integrated value chain into an ecosystem that is horizontal (Beiker et al., 2016).

These accelerated current and forthcoming transformations will most likely cause further challenges for OEMs (Original Equipment Manufacturers) in their effort to adapt to those new market conditions, with their large sizes and bureaucratic processes causing possible obstacles endangering their product competitiveness, market shares and brand loyalty. Considering the fact that the car's function will evolve

\footnotetext{
${ }^{1}$ Prague University of Economics and Business, Faculty of Business Administration, CEMS MIM student, nám. W. Churchilla 1938/4, 130 67, Prague, Czech Republic

2 Prague University of Economics and Business, Faculty of Business Administration, Department of Logistics, nám. W. Churchilla 1938/4, 130 67, Prague, Czech Republic

*Corresponding author, phone: +420 608756 296, e-mail: vinsm@vse.cz
} 
from being a status symbol and a transportation mean to representing an extension of living space (Arena, Pau, \& Severino, 2020; Pakusch et al., 2016), the fact that new product development is highly costly for automotive OEMs and that success depends mostly on the new product acceptance in a market (Townsend \& Calantone, 2013), it is evident that OEMs are about to face increasing challenges and risks.

Taking into account the particular importance the automotive industry has in the economy of the Czech Republic and Slovakia, this paper focuses on exploring the attitudes towards new automotive brands, the brand image of big tech companies, the perceptions regarding the cooperation between car manufacturers and tech companies, the factors that drive purchasing of new brands, and the willingness to pay for vehicles of big tech brands.

\section{LITERATURE REVIEW}

\subsection{Innovation and OEMs}

The automotive industry is being characterized by often changes, disruptions and on-going innovation (Beiker et al., 2016; Ferràs-Hernández, Tarrats-Pons, \& Arimany-Serrat, 2017; Narla, 2013; Townsend \& Calantone, 2013). However, OEMs, in this sector at the same time face limits in their effort to implement new ideas outside of their main current supply chains. Maintaining and enhancing their customer relevance and envisioning the future are of paramount importance (Dziallas, 2020; Wilhelm \& Dolfsma, 2018) and exploring consumers' perceptions and preferences is crucial factor in navigating this dynamic environment.

Further, research has shown that innovation in the automotive sector is driven by both the OEMs and some of their suppliers. OEMs very often outsource several elements of their production and prefer to invest in generating innovations, while at the same time modular structures facilitate accelerated innovation processed by more flexible OEM suppliers (Lee \& Berente, 2012; Townsend \& Calantone, 2013; Wilhelm \& Dolfsma, 2018).

\subsection{New entrants in the automotive sector}

The automotive sector is going through transformations as new entrants launch disruptive technologies, develop new business models and employ new strategies, challenging the status quo of automotive OEMs and the way they do business. Those new entrants will possibly transform the automotive value chains from vertically integrated ones to horizontally structured ecosystems. In such an environment, current OEMs face the challenge to make more efficient their core operations and to outsource the less important ones in a more systematic way (Beiker et al., 2016). As the car is slowly but steadily being transformed from a hardware-oriented machine to a software-oriented product with added service elements, the role of new entrants that have a strong background on digital technologies will be enhanced as well (Diekhof, 2015). The concept of "connected car" is changing the automotive industry by creating new ecosystems and new business opportunities for both startups and more established companies, but at the same time creates new threats for traditional automotive manufacturers (Ferràs-Hernández, Tarrats-Pons, and Arimany-Serrat, 2017).

In addition, tech giants like Apple have such enormous market capitalizations that can easily invest heavily into the automotive industry if they decide to do so (for example at the beginning of 2021 Apple had 196 billion US dollars on hand for investments while Ford Motor Company's market capitalization was 46 billion US dollars). It is already publicly known that Apple approached Nissan and Hyundai asking them to produce a car with the Apple brand, but those inquiries were for the moment turned down as traditional car manufacturers wouldn't like to end up being suppliers of hardware to big tech companies (Inagaki, 2021; McGee, 2021). In addition, Google created in 2018 its daughter company named Waymo that operates in the autonomous ridesharing sector and competes with companies such as Uber and Lyft (LeBeau, 2018), while General Motors wants to compete in this market with its daughter firm named Cruise (Said, 2020). Those developments show how dynamic the current environment is and that car 
manufacturers should explore mutual beneficial ways of cooperation with powerful companies from the technological sector.

Another driver of change in the automotive sector is the technology of autonomous vehicles, with traditional car manufacturers such as BMW, Mercedes-Benz, Nissan, Toyota, and General Motors trying to lead the way but also new entrants such as Tesla, Goodle, Uber and numerous startups wanting to be drivers of those new changes. When Tesla started competing in the automotive sector, it followed an attacker's advantage strategy based on innovation as it addressed several concerns regarding electric vehicles (range issues, performance, charging network) while it integrated new technologies in the cars such as autopilot and in-car services (Chen \& Perez, 2018; Thomas and Maine, 2019). Additionally, Tesla followed a strategy of sharing their patents so as to support the EV (Electric Vehicle) sector but also in order to enhance its image. This approach it seems to have paid off as it has generated more interest and attracted more customers. Open innovation tends to be a new norm in the automotive industry (Moritz et al., 2015).

At the same time, some tech companies have decided to enter the automotive industry not as direct competitors to the traditional car manufacturers as Tesla did, but to create alliances with OEMs. For example, Nvidia provides AI (Artificial Intelligence) and deep learning software while Intel provides software, processors and sensors in the automotive sector (Coppola \& Ludlow, 2021; Intel, 2021; Nvidia, 2021a; Nvidia, 2021b). In the future, software will probably be a more important component of cars compared to the hardware as it happened for computers and mobile phones, so this approach might be long-term suitable for companies in the tech industry (Perkins and Murmann, 2018; Nvidia, 2021a). Those forthcoming transformations will create both opportunities and challenges for the companies that operate in the traditional supply chains.

\subsection{Branding in automotive}

Research has shown that main drivers of loyalty towards a car brand are involvement with car characteristics and what the brand stands for (Loureiro, Sarmento, and Le Bellego, 2017). Also, researchers have demonstrated that product innovation has a positive effect on brand image and brand trust (Hanaysha, Hilman, and Abdul-Ghani, 2014), and that brand trust mediates the relationship between brand personality and brand loyalty (Ahmad Mabkhot, Shaari, and Md. Salleh, 2017).

However, it seems that there is a negative correlation between technology anxiety and brand loyalty (Abd Aziz, 2016) demonstrating that new technologies when incorporated in cars need to be as user friendly as possible. In addition, brand heritage seems to have a strong effect on brand image in the automotive industry and consumers feel less uncertainty when they purchase cars from brands with significant heritage and history (Wiedmann et al., 2011). This fact gives a possible significant competitive advantage to traditional car manufacturers against tech industry new entrants in the automotive sector. Older male customers tend to be more loyal customers, while consumers who change their vehicle often, tend to be less loyal (Jørgensen, Mathisen, \& Pedersen, 2016).

\section{METHODOLOGY}

To address the research's objectives, qualitative methodology was followed as this approach enables the interviewees to openly and freely express their feelings, thoughts and attitudes, and even reveal sensitive information, while the interviewer can analyze the data taking into consideration the background information and current conditions of the interviewee (Goldman, 1962; Malhotra, Birks \& Wills, 2012).

More specifically, semi-structured in-depth interviews of 15 Czech interviewees and 15 Slovak interviewees took place. All participants were young professionals in urban areas, and they were selected based on their age (25-40 years old) and their country of origin and residence (Czech Republic and Slovakia). An interview guide was developed, and the sequence of the questions was in such order to ensure the logical structure and flow of the conversation. All in-depth interviews took place online due to 
COVID-19 pandemic restrictions. The average time of the interviews was 50 minutes and saturation point was reached.

The data were analyzed using the six-step thematic analysis process (data familiarization, initial code generation, assembling into overarching themes, theme reviewing, defining themes, report production) to identify and interpret patterns and relevant themes in the gathered qualitative data (Braun \& Clarke, 2006).

\section{MAIN FINDINGS}

Based on the aforementioned steps of the thematic analysis, the data were categorized and analyzed and as a result, some significant themes presented in this part were formed. More specifically, five main themes were identified: Attitudes towards new automotive brands, Brand image of big tech companies and the spillover effect, Perceptions regarding the cooperation between car manufacturers and tech companies, Purchasing drivers of new brands and Willingness to pay for big tech brands in automotive.

\section{Theme 1: Attitudes towards new automotive brands}

The analysis of data showed that in general, participants had a positive attitude and were rather welcoming towards new players in the automotive industry. However, some participants would still be more open towards purchasing one of the traditional car brands in comparison to new entrants in the market. The reasons that drive such preference towards traditional brands are the lack of brand experience and history of new players and lack of personal experience with such vehicles. Participants identified that for brands of cars to be successful in the market they need to at least match or even outperform the traditional car brands in design, performance, and functionality. Moreover, results showed that it seems that there is a strong connection between electric cars and new brands. Out of all new brands, Tesla was the most well-known and upheld brand, that is still viewed as something exciting and new by the respondents. Indeed, many participants perceive Tesla as a good benchmark for both prospective new entrants in the automotive sector and for current electric car production companies. The case of Tesla supports the findings of previous research that product innovation has significant positive impact on trust and brand image (Hanaysha, Hilman, and Abdul-Ghani, 2014).

However, some respondents didn't have a positive attitude towards the scenario of technology giants (such as Apple, Xiaomi, or Google) offering vehicles of their own brand. The reasons of this rather negative attitude stem from the lack of trust towards the hardware elements of cars produced by tech companies due to lack of experience in the automotive industry, the departure from the original brand focus, and concerns regarding the potential acquisition of way too much power and access to personal data by companies that are already dominating the global economy.

\section{Theme 2: Brand image of big tech companies and the spillover effect}

Further analysis revealed that the brand image of big tech companies can be carried over to potential new products in the automotive industry. It seems that this effect applies for both negative and positive perceptions about the tech brand. However, this brand image spillover effect appears to impact elements of the car that are connected to the company's field of expertise, not the entire vehicle. For instance, a car by Google would be expected to be less pricey than its competitors, having many technological features, and a good software but a rather simple and user-friendly design. At the same time though, the expectations regarding the hardware elements are lower compared to products of traditional car manufacturers as this is not Google's strong area in terms of expertise and supply chain access of car components. Moreover, tech new entrants seem to not be perceived as trustworthy car manufacturers. Reliability and functionality of these vehicles will face potential scrutiny even by early adopters in the market as purchasing a car for many consumers is a substantial expense and investment. In addition, data analysis showed that a car by Apple is expected to compete against premium brands of electric cars such as Tesla and Mercedes Benz.

\section{Theme 3: Perceptions regarding the cooperation between car manufacturers and tech companies}

The findings showed that the young professionals see the cooperation of car manufacturers with tech companies in a positive light, particularly, when this cooperation aims to improve the final product, lower 
its price or make the production more environmentally friendly. If the cooperation had taken place again in the past between such types of companies, this seems to improve further the positive attitude towards the cooperation. Further, if the tech company is considered trustworthy and expert in its field, then this enhances the positive attitudes towards the collaboration.

However, many participants will need to see first-hand the functionality of the end product in order to accept this cooperation as positive and to find the car attractive enough for purchasing. It seems that the end product will play a far more important role as driver of purchasing decision, because the cooperation between car manufactures and tech companies is only viewed as "nice-to-have" and not as game changer.

\section{Theme 4: Purchasing drivers of new brands}

The in-depth interviews revealed that the main factors that would drive the purchasing of new car brands are price, functionality of the vehicle, groundbreaking technologies and good reviews. Big tech companies like Apple probably should not rely just on the brand awareness and brand image they already have, as they are not considered experts in the automotive market. Young professionals seem to continue trusting and preferring traditional car manufacturers' brands.

Furthermore, it seems that consumers expect that the tech companies that will decide to enter the automotive industry will launch differentiated products and expect that the features of the cars, and the price-performance balance should at least match or even excel the current offerings in the market.

Regarding the practice of a tech company's car being manufactured by an incumbent brand as white label product and then being rebranded, is viewed with skepticism as consumers seem not to trust this approach.

\section{Theme 5: Willingness to pay for big tech brands in automotive}

The analysis of the 30 in-depth interviews showed that young professionals' believe that the tech companies are not experienced when it comes to the automotive industry activities and this belief is the reason why they are not willing to pay more for a car that has the big technological company's brand name. It seems like even the early adopters would not be willing to pay more for such a vehicle. Respondents (both in Czech Republic and Slovakia) think that a fair price should match or be lower than the prices of well-established automotive manufacturers. Such prices should be combined with functionality of the new car, being ecologically friendly and having interesting design.

\section{CONCLUSIONS}

The current research effort revealed that participants have in general positive attitudes towards the tech companies that want to enter the automotive sector. They view in positive light those new efforts, however they still put more trust into traditional car manufacturers and value brand heritage in the automotive industry. Further, many respondents had positive attitudes towards Tesla. It seems that Tesla's approach towards educating customers about electric cars, addressing their concerns associated with them (e.g. range, charging network) and sharing patents in the market has paid off, confirming previous research findings (Chen \& Perez, 2018).

In addition, participants expressed concerns towards potential cars by companies such as Apple or Google as they seem not to trust their hardware experience, however the positive image that they have in high tech industry could potentially enhance their image as software and new technology providers in the automotive industry. In addition, many young professionals that participated in the current research, were not willing to pay extra for a car branded by tech companies due to their lack of experience in the automotive industry.

Lastly, our findings showed that participants were rather positive towards the cooperation between traditional car manufacturers with tech companies within a frame where the tech companies focus on their expertise (e.g. developing software for cars) and contributing in a better outcome (e.g. more advanced car features). 


\section{References}

Abd Aziz, S. 2016. Does Fear of New Car Technologies Influence Brand Loyalty Relationship? Journal of Marketing Management, 4(1), 125-136. https://doi.org/10.15640/jmm.v4n1a12

Ahmad Mabkhot, H., Shaari, H., \& Md. Salleh, S. 2017. The Influence of Brand Image and Brand Personality on Brand Loyalty, Mediating by Brand Trust: An Empirical Study. Jurnal Pengurusan, 50, 71-82. https://doi.org/10.17576/pengurusan-2017-50-07

Arena, F., Pau, G., \& Severino, A. 2020. An Overview on the Current Status and Future Perspectives of Smart Cars. Infrastructures, 5(7), 53. https://doi.org/10.3390/infrastructures5070053

Atalay, M., Anafarta, N., \& Sarvan, F. 2013. The Relationship between Innovation and Firm Performance: An Empirical Evidence from Turkish Automotive Supplier Industry. Procedia - Social and Behavioral Sciences, 75, 226-235. https://doi.org/10.1016/j.sbspro.2013.04.026

Beiker, S., Hansson, F., Suneson, A., \& Uhl, M. 2016. How the convergence of automotive and tech will create a new ecosystem. McKinsey \& Company. Retrieved from https://www.mckinsey.de/ /media/McKinsey/Industries/Automotive\%20and\%20Assembly/Our\%20I nsights/How $\% 20$ the $\% 20$ convergence $\% 20$ of\%20automotive $\% 20$ and $\% 20$ tech $\% 20$ will\%20create $\% 20$ a $\% 20$ new $\% 20$ ecosystem/How-the-convergence-of-automotive-and-tech-will-create-a-new-ecosystemfinal.pdf

Braun, V., \& Clarke, V. 2006. Using thematic analysis in psychology. Qualitative Research in Psychology, 3(2), 77-101. https://doi.org/10.1191/1478088706qp063oa

Chen, Y., \& Perez, Y. 2018. Business Model Design: Lessons Learned from Tesla Motors. Towards a Sustainable Economy, 53-69. https://doi.org/10.1007/978-3-319-79060-2_4

Coppola, G., \& Ludlow, E. 2021. Intel's Mobileye Plans Self-Driving Cars for the Masses by 2025. Bloomberg. Retrieved from https://www.bloomberg.com

Diekhof, J. 2015. Do entrants increase incumbents' innovation activity? Escaping the lock-in, stimulating technological change and the transition towards environmentally friendly vehicles. Journal of Innovation Economics, 16(1), 101. https://doi.org/10.3917/jie.016.0101

Dziallas, M. 2020. How to evaluate innovative ideas and concepts at the front-end? Journal of Business Research, 110, 502-518. https://doi.org/10.1016/j.jbusres.2018.05.008

Ferràs-Hernández, X., Tarrats-Pons, E., \& Arimany-Serrat, N. 2017. Disruption in the automotive industry: A Cambrian moment. Business Horizons, 60(6), 855-863. https://doi.org/10.1016/j.bushor.2017.07.011

Goldman, A. E. 1962. The Group Depth Interview. Journal of Marketing, 26(3), 61-68. https://doi.org/10.1177/002224296202600313

Hanaysha, J., Hilman, H., \& Abdul-Ghani, N. H. 2014. Direct and Indirect Effects of Product Innovation and Product Quality on Brand Image: Empirical Evidence from Automotive Industry. International Journal of Scientific and Research Publications, 4(11), 1-7. Retrieved from https://citeseerx.ist.psu.edu/viewdoc/download?doi=10.1.1.651.7100\&rep=rep1\&type=pdf

Intel. 2021. Automotive FPGA - Intel® FPGAs. Retrieved February 27, 2021, from https://www.intel.com/content/www/us/en/automotive/products/programmable/overview.html 
Jørgensen, F., Mathisen, T. A., \& Pedersen, H. 2016. Brand loyalty among Norwegian car owners. Journal of Retailing and Consumer Services, 31, 256-264. https://doi.org/10.1016/j.jretconser.2016.04.001

Konicarová, K. 2019. Mobility. CzechInvest. Retrieved from https://www.czechinvest.org

LeBeau, P. 2018. Waymo starts commercial ride-share service. CNBC. Retrieved from https://www.cnbc.com

Lee, J., \& Berente, N. 2012. Digital Innovation and the Division of Innovative Labor: Digital Controls in the Automotive Industry. Organization Science, 23(5), 1428-1447. https://doi.org/10.1287/orsc.1110.0707

Loureiro, S. M. C., Sarmento, E. M., \& Le Bellego, G. 2017. The effect of corporate brand reputation on brand attachment and brand loyalty: Automobile sector. Cogent Business \& Management, 4(1), 1360031. https://doi.org/10.1080/23311975.2017.1360031

Malhotra, N. K., Birks, D. F., \& Wills, P. A. 2012. Marketing Research (4th ed.). Hallbergmoos, Germany: Pearson.

McGee, P. 2021. Apple approached Nissan to work on autonomous car project. Financial Times. Retrieved from https://www.ft.com

Moritz, M., Redlich, T., Krenz, P., Buxbaum-Conradi, S., \& Wulfsberg, J. P. 2015. Tesla Motors, Inc.: Pioneer towards a new strategic approach in the automobile industry along the open source movement? 2015 Portland International Conference on Management of Engineering and Technology (PICMET), 85-92. https://doi.org/10.1109/picmet.2015.7273032

Narla, S. R. K. 2013. The Evolution of Connected Vehicle Technology: From Smart Drivers to Smart Cars to... Self-Driving Cars. ITE JOURNAL, 22-26. Retrieved from https://citeseerx.ist.psu.edu/viewdoc/download?doi=10.1.1.441.7658\&rep=rep1\&type=pdf

NVidia. 2021a. Accelerating Automotive Breakthroughs with NVIDIA DRIVE Partners. Retrieved February 27, 2021, from https://www.nvidia.com/en-us/self-driving-cars/partners/

NVidia. 2021b. Self-Driving Cars Technology \& Solutions from NVIDIA Automotive. Retrieved February 27, 2021, from https://www.nvidia.com/en-us/self-driving-cars/

Pakusch, C., Bossauer, P., Shakoor, M., \& Stevens, G. 2016. Using, Sharing, and Owning Smart Cars - A Future Scenario Analysis Taking General Socio-Technical Trends into Account. Proceedings of the 13th International Joint Conference on E-Business and Telecommunications, 19-30. https://doi.org/10.5220/0005960900190030

Pennanen, T. 2017. MaaS Global aims to revolutionise mobility. Retrieved March 6, 2021, from https://www.myhelsinki.fi/en/business-and-invest/maas

Perkins, G., \& Murmann, J. P. 2018. What Does the Success of Tesla Mean for the Future Dynamics in the Global Automobile Sector? Management and Organization Review, 14(3), 471-480. https://doi.org/10.1017/mor.2018.31

Pravda. 2019. Automobilky sa radikálne zmenia, čaká to aj Slovensko. Pravda.Sk. Retrieved from https://ekonomika.pravda.sk

Said, C. 2020. Cruise deploys true robot cars in S.F. - no backup drivers behind wheel. San Francisco Chronicle. Retrieved from https://www.sfchronicle.com 
SME. 2020. Rekordné číslo. Slovensko ostáva lídrom vo výrobe áut na obyvatel’a. Ekonomika.Sme.Sk. Retrieved from https://ekonomika.sme.sk

Talay, M. B., Calantone, R. J., \& Voorhees, C. M. 2013. Coevolutionary Dynamics of Automotive Competition: Product Innovation, Change, and Marketplace Survival. Journal of Product Innovation Management, 31(1), 61-78. https://doi.org/10.1111/jpim.12080

Thomas, V. J., \& Maine, E. 2019. Market entry strategies for electric vehicle start-ups in the automotive industry - Lessons from Tesla Motors. Journal of Cleaner Production, 235, 653-663. https://doi.org/10.1016/i.jclepro.2019.06.284

Townsend, J. D., \& Calantone, R. J. 2013. Evolution and Transformation of Innovation in the Global Automotive Industry. Journal of Product Innovation Management, 31(1), 4-7. https://doi.org/10.1111/jpim.12075

Wiedmann, K.-P., Hennigs, N., Schmidt, S., \& Wuestefeld, T. 2011. Drivers and Outcomes of Brand Heritage: Consumers' Perception of Heritage Brands in the Automotive Industry. Journal of Marketing Theory and Practice, 19(2), 205-220. https://doi.org/10.2753/mtp1069-6679190206

Wilhelm, M., \& Dolfsma, W. 2018. Managing knowledge boundaries for open innovation - lessons from the automotive industry. International Journal of Operations \& Production Management, 38(1), 230-248. https://doi.org/10.1108/ijopm-06-2015-0337 